\title{
Trauma, History, and the Limits of Language
}

\author{
Emanuela Tegla, PhD \\ University of Medicine and Pharmacy, Targu-Mures, Romania
}

Doi: 10.19044/esj.2018.v14n36p117 URL:http://dx.doi.org/10.19044/esj.2018.v14n36p117

\begin{abstract}
The question of adequate representation through words, of a proper correlation between object and word, signifier and signified, has always been at the forefront in literary studies. This conundrum has acquired new dimensions in the last century, due to the traumatic events that marked it and led to an irrepressible need to confess and bear witness, in fictional as well as in non-fictional form. This dimension of trauma has unsettled the relationship between what words are taken to represent and the reality they stem from, as well as the very possibility of putting in words certain realities denoting unspeakable individual or collective trauma. After a short theoretical introduction into the concept of trauma, the present essay will seek to analyse a number of instances, from prose, poetry and non-fiction writings, which exemplify the various dimensions of the difficulty of talking about trauma.
\end{abstract}

Keywords: Trauma, language, Coetzee, Celan, Levi, Manea

\section{Introduction}

In general terms, trauma refers to a terrifying experience which causes physical and psychological harm. A crucial element of trauma consists in the fact that it affects the victim's sense of self and of identity, to the extent that it becomes shattered, often unrecognisable (above all, to the victim herself). This profound alteration is due to the evil character of the experience itself, but also, since it is an unwarranted interruption in the natural course of life, to the act of invalidation it performs on the meaningmaking effort of an individual.

The ability of words to express, to communicate a traumatic reality has been questioned by many thinkers and philosophers, especially in the second part of the twentieth-century. Shoshana Felman notes that the term 'trauma' is understood to designate "a shock that creates a psychological split or rupture, an emotional injury that leaves lasting damage in the psyche" (Felman, 2002, 171). Leigh Gilmore mentions the consensus developed among trauma theoreticians that trauma is fundamentally 
unrepresentable, because "language fails in the face of trauma, [while] trauma mocks language and confronts it with its insufficiency" (Gilmore, 2001, 6).

Some of the most profound and pertinent observations regarding this problem have been formulated by Walter Benjamin. His concept of the expressionless (das Ausdruckslose), which he coined in the 1924-25 essay on "Goethe's Elective Affinities," has been employed in theoretical analysis of literature, as well as in readings of novels and in discussions of justice and the law. The difficulty of bearing witness, that is, of giving voice to those who suffered trauma and trying to communicate its implications to others is prominent in any approach of the topic.

In his discussion of the "expressionless," Benjamin associates literature with the uncommunicable, that is, with aspects of reality that cannot be expressed in words. This dimension of language is evident both in fictional and non-fictional writings, on several levels. First, there is the impossibility, or the difficulty of expressing a traumatic reality as evidenced by characters in works of fiction. In Coetzee's novel Waiting for the Barbarians, for example, the main character, the Magistrate, finds himself in the unsettling position of not being able to find the right words to express a morally atrocious reality, unfolding before his very eyes. Moreover, he recognises not only the resistance of language in the face of atrocities, but also the impossibility of invoking moral grounds which might prevent a morally corrupt person from doing evil. After admitting that he is "no orator," the Magistrate meditates: "What would I have said if they had let me go on? That it is worse to beat a man's feet to pulp than to kill him in combat? That it brings shame on everyone when a girl is permitted to flog a man? That spectacles of cruelty corrupt the hearts of the innocent? The words they stopped me from uttering may have been paltry indeed, hardly words to rouse the rabble" (Coetzee, 2004, 118).

For several contemporary writers, the concept of the "expressionless" acquires yet another dimension, already mentioned by Felman, following Levinas: that of giving a voice to those who have been deprived of the power of expressing themselves by the violence they suffered (Felman, 2002). Nevertheless, for Coetzee, the language in which he writes and through which he might be perceived of as giving voice to the voiceless becomes problematic from yet another perspective: not only is language rather limited in expressing atrocious realities, but, given the historical particularities of South Africa, the English language might be considered as downright inappropriate for such an endeavour.

This idea is expressed both by Coetzee's fictional characters and by himself, in his non-fictional texts. As regards the former, the protagonist of Disgrace points out that English, the language of the colonizers, is "an unfit 
medium for the truth of South Africa" (Coetzee, 1999, 117). Given the social, historical, and ethical particularities of the country, the English language lacks, thus, the legitimacy necessary for containing or expressing the reality of South Africa because of the sedimented layers of historical injustice which are inherent in it, and also because it belongs to a different continent, to a different history.

The inadequacy of language to convey traumatic events and inner suffering acquires a pivotal significance in the life and work of the great twentieth-century poet Paul Celan. He had direct experience of the forced labour camps and both his parents were killed by German Nazis. In his case, the implications of language as an inadequate medium capable of conveying atrocious realities extend well beyond the difficulty of finding the right words in order to achieve meaningful communication. In what follows, we shall address these two aspects in some detail.

The inability or the ineffectiveness of language to create a reality through words which can be at least similar, to a certain extent, to the one that inspired it pervades the work of those who had the experience of extreme suffering during the wars. Primo Levi, for example, when trying to communicate to the reader the truth about his experience in Auschwitz and to make him/her see and understand the pain and humiliation the prisoners were subjected to, finds himself in the impossibility of doing so, because the reality of those limit-experiences far exceeds the humanly conceivable. Shortly after their arrival at the camp, the group he finds himself in is forced to take a shower, in miserable conditions. He attempts to transmit the reader and make him understand the extreme vulnerability and the animal fear those men felt - not because of the conditions of the place, but because of the psychologically inhuman treatment they were subjected to: being robbed of their dignity, wondering, in numbing terror, whether they would be killed soon or not (not that day, though, otherwise they would not have been asked to wash themselves). But this honest, painful attempt at meaningful, expressive communication almost fails because, Levi confesses, "our language lacks words to express this offence, the demolition of a man" (Levi, 2003, 32). Confronted with unimaginably harsh situations, language becomes dried-up, devoid of its main function, that of signifying a reality. Simple, common words, such as "hunger," "tiredness," "pain," even the banal "winter" (Levi's examples) are used because there are no others to use, but, in order to convey the extreme suffering the prisoners experienced, "a new, harsh language" would have been necessary. Language reaches, thus, a limit, an unbridgeable gap, beyond which meaningful communicability becomes impossible.

In the case of Paul Celan, the drama of language pervades his entire life and his entire work. The extent to which the drama of having as mother 
tongue the language of the people who killed his parents is well-known; what varies, perhaps, is the degree of relevance attributed to it. Paul Celan did not believe in truth spoken in a language other than one's mother tongue, or in poetry written in a different language. He had to struggle with this predicament his entire adult life. He responded with irrefutable reticence to expectations of confessions or testimonies of his experience in the camps. Yet, he struggled to communicate it, and the moral lessons derived from it, in his poetry. In his famous "Meridian Speech," he expressed a hesitant belief in the possibility of a poem as an "encounter" with the other, but he also drew attention to the fact that one can notice in contemporary poems "a strong tendency towards silence" (Celan, 2003, 48). It is, therefore, a particular type of "encounter," one that emerges from a desperate need to communicate, while fully aware that such communication is only partially possible, if at all.

Being a poet who held the firm conviction that poems can be written in truth only in one's mother tongue, Celan painfully accepted this drama, but in a way that reveals, however subtly, his constant, everyday struggle to come to terms with it. In his "Introduction" to a selection of Celan's poems, Pierre Joris observes that Celan's writing in the German language, apart from the fact that it was his mother tongue, was meant to fulfil another deep, painful need: that of having an impact on the country which was responsible for the tragedy of his parents, to leave a mark on their conscience. Joris recounts Celan's friends' stories about the poet's anxious expectation of reports and reviews of his work in the German newspapers of the time. Following their account, Joris notes, Celan's attitude and reaction is not linked to the common pride of the expatriate, rejoicing at the mention of his name in his mother tongue. Rather, it is "that of a deeply wounded man, hoping that the strategies of his solitary struggles are paying off" (Joris, 2005, 20). In the same introduction, Joris uses a war metaphor in connection with Celan and his relationship with the German language, explaining his choice by the fact that the poet felt the need to counter the attacks he perceived as coming from Germany and also, at some level, to "revenge for the death of his parents" (Ibid, 9).

How can revenge (conventionally associated with violence) be achieved through such seemingly meagre means as words, or poems? Such a possibility appears even less likely if we consider the premise formulated above, namely that words can hardly express the full truth about an atrocious reality. Yet, the act of poetical creation as revenge against the mother tongue permeates Celan's work. This seemingly incomprehensible dimension of it can be illuminated by invoking another Auschwitz survivor's stance on the inability of language to express extreme suffering: 
It would be totally senseless to try and describe here the pain that was inflicted on me [...]. The pain was what it was. Beyond that there is nothing tosay. Qualities of feeling are as incomparable as they are indescribable.They mark the limit of the capacity of language to communicate. If someonewanted to impart his physical pain, he would be forced to inflict itand thereby become a torturer himself (Améry, 1980, 33)

The idea that the only possibility of communicating to an other the pain one suffered is only by inflicting it and thus turning from victim into torturer should not be taken literally, obviously. Yet, Améry's understanding of the limits of language illuminates certain connotations in Celan's troubled relationship with his mother tongue. Petre Solomon, a lifelong friend of Celan, rightly observes that his entire poetry is "a desperate dialogue" between him and his mother tongue. Solomon associates Celan's tendency in his later poems to include foreign words and structures in his poetry with a form of violence the poet attempts to do to the language which is both his mother tongue and the language of the victims of the Nazi Holocaust. If a language contains embedded within it a certain vision of the world, the fact that the German language has been capable of leading to such atrocities renders its use in poetic form highly problematic. The drama of having such a language as the only possible means of expressing himself is poignantly signalled by Solomon, who observes that Celan attempted to subject "the German language - 'this German language of mine, et qui reste douloureusement mienne' (and which remains painfully mine), as he confessed in a letter - to pressures which were equivalent, in a sense, to the moral pressures and humiliations he himself endured" (Solomon, 2008, 171).

The centrality of the mother tongue in the life and work of a writer or a poet (and not only), its inescapable character can be hardly overestimated. Norman Manea suggestively equates it with a placenta: "For a writer, language is a placenta. Language is not only a sweet and glorious conquest, but legitimization, a home" (Manea, 2012, 257). Manea himself fled the communist persecutions in his native Romania and left for Germany first and then moved to the US. Language acquires a double significance for him: on the one, hand, it is the medium through which oppression can be promoted and maintained, to the extent that language itself becomes lifeless, "wooden," as he often calls the language used by the Romanian communists. On the other hand, he sees in it the only escape (he confesses he has been able to preserve his mental sanity by struggling to keep alive a 
certain personal interiority and by writing and reading). For Manea, being forced to live in a country which speaks a different language is a trauma in itself: "An author's exile is a terrible trauma for the writer, skinned and unsoiled, forced to replace the internal organs of his linguistic being. It has proven, more than once, to be his suicide" (Ibid, 265).

Such a view of language helps illuminate the drama experienced by writers and poets like Celan, who had no choice but to succumb to the forces of history and live in a foreign linguistic medium. Although he lived in France most of his adult life, Celan never wrote in French, but in German, because, as Manea points out, that was his real home. He had a similar experience, as he confesses: "In New York I still live in the Romanian language, as in Paris Paul Celan lived in German" (Ibid, 269).

Edward Said elaborates on yet another limit of language when employed to communicate traumatic experiences. In his volume on Humanism and Democratic Criticism, Said struggles to convince himself that there is no other choice but to accept the immutable fact that one is forced to use the same language as those who are morally bankrupt. Although he refers specifically to the State Department of the US and the linguistic acrobatics they use in order to justify the war in Iraq, Said's observations can be extended to other instances as well. He realizes that the common language he and those in power use does not lead to a common understanding, yet, he is aware that the former must be employed in order to achieve a sort of reconnection with realities which those who, by accidents of life, can afford, morally above all, to ignore atrocious realities. One may question how (or what) such people, "these vastly overprivileged antagonists of mine," as Said calls them, can understand, given not only their (comfortable) life experience, but also their propensity towards simplifying and diminishing the truth.

The same idea of the limit imposed by one's sheltered life experience in understanding trauma is expressed also in another of Coetzee's books, namely in Elizabeth Costello. The 'protagonist' of the book, a writer who is invited to give lectures on her novels and on writing in general, speaks about "The Problem of Evil" (the sixth lecture, held in Amsterdam). After referring to several morally problematic instances of the twentieth century - the Nazis, Paul West's representation of an unsuccessful attempt to kill Hitler, the sufferings of innocent people, etc., she reflects, in her mind, before the lecture is due to end, that she should not have agreed to attend and speak at that conference. The reason for which she regrets her decision is that she realises that the addressees of her discourse might miss the 'message' she is trying to convey, because "a limit has been reached, the limit of what can be achieved with a body of balanced, well-informed modern folk in a clean, well-lit lecture venue in a well-ordered, well-run 
European city in the dawn of the twenty-first century" (Coetzee, 2004, 175). Thus, she alludes here to limits imposed not only by language, but by life experience and temporal distance as well, the dawn of the new century rendering, perhaps, such atrocities difficult to grasp.

\section{Conclusion}

It is a universally accepted fact that language occupies a crucial place in history. As Sunday Danladi points out, "the primacy of language in human history has never been in doubt. In political and social policy, language functions as a vehicle of interaction and as an instrument of communication" (S. S. Danladi, 2013, 2). As far as literature is concerned, the importance of language, of experiencing the reality created by language can be hardly overestimated. Yet, as pointed out above, words have certain limits as regards their effectiveness of transmitting vividly or accurately the trials or the knowledge of the author. We have mentioned some of them the difficulty to express in words traumatic events, the inadequacy of using a certain language (German, the language of the perpetrators, in the case of Celan, or English, the language of the colonizers, in the case of Coetzee), or the insurmountable gap that is created at the encounter of two very different realities within the process of communicating, through words, traumatic experiences. Even if one were to struggle to create for the reader images that are as close to the evil reality represented as possible, there is the danger of subjecting her/him to a similarly painful experience. In psychology, this phenomenon is widely recognised as the listener's trauma - the vicariously experienced ordeal of the psychologist who, upon hearing traumatic stories and testimonies, appropriates and, to a certain extent, experiences them as well.

This aspect is poignantly signalled by Coetzee, in Elizabeth Costello. In the above mentioned lecture, suggestively titled "The Problem of Evil," in which she discusses Paul West's novel on Hitler and Hitler's attempted assassination, Costello warns the reader about the dangers of spelling out, in a book, gruesome details of horrific experiences. Such insistence on realistic representation and description is called by Costello "obscene," because there should be a different kind of limit, which should prevent such things from being made public. Rather, they should be "covered up and hidden for ever in the bowels of the earth, like what goes on in the slaughterhouses of the world, if one wishes the save one's sanity" (Coetzee, 2004, 159). This type of limit is one of the reasons that account for writers' preference for allegories, metaphors, and so forth, which create, in tragedies, for example, a reality that not only is bearable for the reader, but it offers, as Aristotle pointed out, the possibility of identifying with the character and reaching a state of catharsis, which has the potential not only of transforming negative 
unwanted emotions, but also of developing the reader's empathetic imagination.

One can only insist, as Said does, on the necessity of reclaiming and reconnecting the (human) subject to the reality those in power choose to ignore or to misrepresent. It is one of the principal functions of writing in general, that of responding to the imperious human need to communicate, as well as of bearing witness and giving voice to the "expressionless," and of challenging the shortcomings and limits of language.

\section{References:}

1. Améry, J. (1980). At the Mind's Limits. Contemplations by a Survivor on Auschwitz and Its Realities. Translated by Sidney Rosenfeld \& Stella P. Rosenfeld. Bloomington: Indiana University Press.

2. Celan, P. (2005). Selections. Edited and with an Introduction by Pierre Joris. Berkeley, CA: University of California Press.

3. Coetzee, J. M. (2004). Waiting for the Barbarians. London: Vintage.

4. ------- (2004). Elizabeth Costello. Eight Lessons. London: Vintage.

5. ------- (1999). Disgrace. London: Vintage.

6. Danladi, Shaibu Sunday (2013). "Language Policy: Nigeria and the Role of English Language in the $21^{\text {st }}$ Century" (European Scientific Journal, Vol. 9, No. 17.

7. Felman, S. (2002). The Juridical Unconscious. Trials and Traumas in the Twentieth Century. Cambridge, MA: Harvard University Press.

8. Gilmore, L. (2001). The Limits of Autobiography. Trauma and Testimony. Ithaca and London: Cornell University Press.

9. Levi, P. (2003). If This is a Man\&The Truce. Translated by Stuart Woolf. London: Abacus.

10. Said, E. (2004). Humanism and Democratic Criticism. Hampshire: Palgrave Macmillan.

11. Solomon, P. (2008). Paul Celan. DimensiuneaRomânească. Bucuresti: Art. Forthcoming in English (2018): Paul Celan. The Romanian Dimension. With an Introduction by J. M. Coetzee. Translated by EmanuelaTegla. New York: Syracuse University Press. 